\title{
Arthrobacter antarcticus sp. nov., isolated from an Antarctic marine sediment
}

\author{
Pavan Kumar Pindi, Ruth Manorama, Zareena Begum and S. Shivaji \\ Centre for Cellular and Molecular Biology, Uppal Road, Hyderabad 500 007, India
}

Correspondence

S. Shivaji

shivas@ccmb.res.in

\begin{abstract}
A bacterial strain, SPC26 ${ }^{\top}$, was isolated from a sediment sample of the Southern Ocean off Antarctica. The strain was Gram-staining- and catalase-positive and contained lysine and alanine in the cell-wall peptidoglycan. The major cellular fatty acids were anteiso- $\mathrm{C}_{15: 0}(54.92 \%)$, iso- $\mathrm{C}_{15: 0}(11.47 \%)$, anteiso- $\mathrm{C}_{17: 0}(6.48 \%)$ and anteiso- $\mathrm{C}_{15: 1}(6.38 \%)$ and the major menaquinones were MK-8, MK-9 and MK-10. The major polar lipids were phosphatidylethanolamine and diphosphatidylglycerol. The $\mathrm{G}+\mathrm{C}$ content was $68 \pm 0.5 \mathrm{~mol} \%$. Based on 16S rRNA gene sequence similarities, the nearest phylogenetic neighbours of strain SPC26 ${ }^{\top}$ were identified as Arthrobacter gangotriensis Lz1y ${ }^{\top}(98.8 \%)$, A. sulfureus DSM $20167^{\top}$ (98.6\%), A. psychrophenolicus DSM $15454^{\top}$ (97.9\%) and A. kerguelensis KGN15 ${ }^{\top}$ (97.5). With these strains, strain SPC26 ${ }^{\top}$ exhibited DNA-DNA relatedness values of $36,21,12$ and $10 \%$, respectively. Therefore, on the basis of $16 \mathrm{~S}$ rRNA gene sequence comparisons, phylogenetic analysis, phenotypic characteristics and DNA-DNA relatedness, it is proposed that strain SPC26 ${ }^{\top}$ represents a novel species of Arthrobacter, for which the name Arthrobacter antarcticus

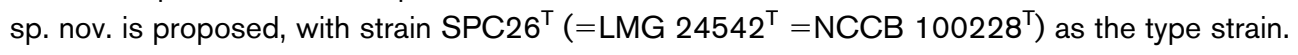

The genus Arthrobacter was first proposed by Conn \& Dimmick (1947) with Arthrobacter globiformis as the type species. All Arthrobacter species are strictly aerobic, catalasepositive and sporogenous rod-shaped bacteria that display coryneform morphology and contain A-type (A3 $\alpha$ or A4 $\alpha$ ) peptidoglycan with L-lysine as the dibasic amino acid (Schleifer \& Kandler, 1972). The genus Arthrobacter is phenotypically heterogeneous, and over 52 species have so far been isolated from various sources such as soil (Reddy et al., 2002; Lee et al., 2003; Gupta et al., 2004; Chen et al., 2005), cheese (Irlinger et al., 2005), clinical specimens (Funke et al., 1996; Hou et al., 1998; Wauters et al., 2000; Huang et al., 2005), paintings (Heyrman et al., 2005), seals (Collins et al., 2002), an alpine ice cave (Margesin et al., 2004), fish (Osorio et al., 1999), wastewater reservoir sediment (Roh et al., 2008) and air ( $\mathrm{Li}$ et al., 2004). In this paper, we report the characteristics of a novel Arthrobacter strain isolated from a sediment sample of the Southern Ocean off Antarctica.

Sediment samples were collected from a depth of $400 \mathrm{~m}$ near the Larsemann Hills area $\left(69^{\circ} 22^{\prime} \mathrm{S} 76^{\circ} 06^{\prime} \mathrm{E}\right)$ using a spade box corer and brought to the laboratory. The sample, after suspending $0.1 \mathrm{~g}$ in $1 \mathrm{ml}$ sterile water by vortexing, plating on nutrient agar (NA) $\left(1^{-1}: 10 \mathrm{~g}\right.$ peptone, $10 \mathrm{~g}$ beef extract, $5 \mathrm{~g} \mathrm{NaCl}$ and $20 \mathrm{~g}$ agar) and incubation at $22{ }^{\circ} \mathrm{C}$ for 7 days, yielded $7.9-15.2 \times 10^{3}$ c.f.u. $g^{-1}$. Strain SPC $26^{\mathrm{T}}$

The GenBank/EMBL/DDBJ accession number for the 16S rRNA gene sequence of strain SPC26 $^{\top}$ is AM931709.

An extended neighbour-joining phylogenetic tree based on 16S rRNA gene sequences is available with the online version of this paper. was isolated by repeated subcultivation on NA plates and subjected to a detailed polyphasic taxonomic analysis. Arthrobacter gangotriensis DSM $15796^{\mathrm{T}}$, A. sulfureus DSM $20167^{\mathrm{T}}$, A. psychrophenolicus DSM $154547^{\mathrm{T}}$ and A. kerguelensis DSM $15797^{\mathrm{T}}$ were used as reference strains.

Tryptone soy broth (TSB) (M290; HiMedia) containing $\left(1^{-1}\right) 15 \mathrm{~g}$ pancreatic digest of casein and $5 \mathrm{~g}$ pancreatic digest of soybean meal or NA was used for growth and maintenance of the strain and determination of phenotypic and chemotaxonomic characteristics. A Leitz Diaplan phase-contrast microscope was used to ascertain the morphology and motility of cells. $\mathrm{pH}$ tolerance was determined using TSB adjusted to $\mathrm{pH} 4-10$, at intervals of $1 \mathrm{pH}$ unit, by the addition of $\mathrm{HCl}$ or $\mathrm{NaOH}$. Tolerance of $0-8 \% \mathrm{NaCl}$, at intervals of $1 \%$, was determined on NA with $\mathrm{NaCl}$ omitted. Results were scored after $72 \mathrm{~h}$ of incubation at $22{ }^{\circ} \mathrm{C}$. Other physiological and biochemical characteristics were determined at $22{ }^{\circ} \mathrm{C}$ following Holding \& Collee (1971) and Smibert \& Krieg (1994). Acid production from carbohydrates was tested using a HiCarbohydrate kit (KB009; HiMedia). Utilization of various carbon compounds as the sole carbon source was tested at $22{ }^{\circ} \mathrm{C}$ for 15 days in minimal medium [containing $1^{-1}: 1.2 \mathrm{~g}\left(\mathrm{NH}_{4}\right)_{2} \mathrm{SO}_{4}, 0.5 \mathrm{~g} \mathrm{MgSO}_{4} .7 \mathrm{H}_{2} \mathrm{O}, 0.5 \mathrm{~g} \mathrm{KH}_{2} \mathrm{PO}_{4}$, $0.1 \mathrm{~g} \mathrm{KCl} ; \mathrm{pH} 6.5 \pm 0.2$ ] supplemented with $0.5 \%(\mathrm{w} / \mathrm{v})$ carbon source. The phenotypic characteristics of strain SPC $26^{\mathrm{T}}$ are given in Table 1 and the species description.

Menaquinones and polar lipids were determined in freezedried cells. Menaquinones were extracted as described 
Table 1. Characteristics of strain SPC $26^{\top}$ and type strains of closely related Arthrobacter species

Strains: 1 , Arthrobacter antarcticus sp. nov. $\mathrm{SPC}^{\mathrm{T}} 6^{\mathrm{T}} ; 2$, A. gangotriensis DSM $15796^{\mathrm{T}}$; 3, A. sulfureus DSM $20167^{\mathrm{T}}$; 4, A. psychrophenolicus DSM $15454^{\mathrm{T}} ; 5$, A. kerguelensis DSM $15797^{\mathrm{T}}$. All strains were positive for urease and negative for $\beta$-galactosidase and glycerol utilization.

\begin{tabular}{|c|c|c|c|c|c|}
\hline Characteristic & 1 & 2 & 3 & 4 & 5 \\
\hline Aesculin hydrolysis & - & - & - & + & + \\
\hline Casein hydrolysis & - & + & - & - & + \\
\hline Nitrate reduction & + & - & - & + & - \\
\hline Gelatinase & - & + & + & - & + \\
\hline Phosphatase & + & + & - & - & + \\
\hline \multicolumn{6}{|l|}{ Utilization of: } \\
\hline L-Arabinose & + & + & - & - & - \\
\hline D-Glucose & + & + & - & - & + \\
\hline D-Galactose & + & + & - & - & + \\
\hline Lactose & - & + & - & - & + \\
\hline D-Ribose & - & + & - & - & + \\
\hline L-Rhamnose & + & - & - & + & + \\
\hline D-Xylose & + & + & - & - & + \\
\hline Malonate & + & + & + & - & + \\
\hline D-Xylitol & - & + & + & + & + \\
\hline L-Histidine & - & - & + & - & + \\
\hline
\end{tabular}

by Collins et al. (1977) and were analysed by HPLC (Groth et al., 1997). Polar lipids were analysed by twodimensional TLC using pure lipids as standards following the procedure of Minnikin et al. (1975). The presence of mycolic acids was examined using TLC (Minnikin et al., 1980). DNA was isolated according to the procedure of Marmur (1961) and G+C content (mol\%) was determined from the melting point $\left(T_{\mathrm{m}}\right)$ curves (Sly et al., 1986) obtained using a Lambda $2 \mathrm{UV}$-Vis spectrophotometer equipped with Templab version 2.0 software (Perkin Elmer). Peptidoglycan and cell-wall sugars were prepared and analysed according to the method of Komagata \& Suzuki (1987). The chemotaxonomic characteristics of strain SPC26 ${ }^{\mathrm{T}}$ are given in the species description.

For cellular fatty acid analysis, cells of strain SPC26 ${ }^{\mathrm{T}}$ were grown on TSA at $25{ }^{\circ} \mathrm{C}$ for $72 \mathrm{~h}$. The fatty acid methyl esters were extracted from a loopful of culture according to the instructions of the Sherlock Microbial Identification
System (MIDI) and analysed using gas chromatography (MIDI 6890N GC; Agilent Technologies) equipped with an FID detector (Agilent Technologies). The cellular fatty acids of strain SPC $26^{\mathrm{T}}$ were anteiso- $\mathrm{C}_{15: 0}$ (54.92\%), iso$\mathrm{C}_{15: 0}(11.47 \%)$, anteiso- $\mathrm{C}_{17: 0}(6.48 \%)$, anteiso- $\mathrm{C}_{15: 1}$ $(6.38 \%), \mathrm{C}_{18: 0}(2.42 \%), \mathrm{C}_{16: 0}(2.14 \%), \quad$ iso- $\mathrm{C}_{16: 0}$ $(1.79 \%)$, anteiso- $\mathrm{C}_{16: 0}(1.76 \%), \mathrm{C}_{14: 0}(1.30 \%)$, iso$\mathrm{C}_{15: 1}(1.25 \%)$ and iso- $\mathrm{C}_{19: 0}(1.07 \%)$.

The 16S rRNA gene of strain SPC $26^{\mathrm{T}}$ was amplified from the genomic DNA and sequenced according to Reddy et al. (2000). In the pairwise 16S rRNA gene sequence alignment performed using the ExPASy bioinformatics tool (http:// www.expasy.org), strain SPC26 ${ }^{\mathrm{T}}$ showed $98.8 \%$ similarity to A. gangotriensis $\mathrm{Lzly}^{\mathrm{T}}, 98.6 \%$ to $A$. sulfureus DSM $20167^{\mathrm{T}}, 97.9 \%$ to $A$. psychrophenolicus DSM $15454^{\mathrm{T}}$, $97.5 \%$ to $A$. kerguelensis $\mathrm{KGN}^{\mathrm{T}}{ }^{\mathrm{T}}$ and less than $97.5 \%$ similarity to strains of other species of Arthrobacter with validly published names. To determine the phylogenetic affiliation of strain SPC2 $6^{\mathrm{T}}$, the $16 \mathrm{~S}$ rRNA gene sequence of the strain was aligned with sequences from the type strains of other Arthrobacter species using CLUSTAL w (Thompson et al., 1994) and phylogenetic analysis was carried out as described by Bhadra et al. (2008). In neighbour-joining phylogenetic trees constructed according to Kimura's twoparameter model (Kimura, 1980) using MEGA version 3.1 (Kumar et al., 2004), strain SPC $26^{\mathrm{T}}$ formed a robust clade with A. gangotriensis $\mathrm{Lzly}^{\mathrm{T}}$ with bootstrap support of $97 \%$ in a tree of the most closely related strains (Fig. 1) and $96 \%$ in an extended tree (Supplementary Fig. S1, available in IJSEM Online).

There were various characteristics that indicated that strain SPC $26^{\mathrm{T}}$ is a member of the genus Arthrobacter and is most closely related to A. gangotriensis and A. sulfureus: anteiso- $\mathrm{C}_{15: 0}$ as the major fatty acid, the presence of lysine and alanine as the diamino acids in the peptidoglycan, glutamic acid as the acyl type (A $4 \alpha$ variation), presence of MK-9, aerobic growth, positive catalase reaction, $16 \mathrm{~S}$ rRNA gene sequence similarity and the results of phylogenetic analysis. The strain also differed from its nearest phylogenetic relatives in a number of phenotypic characteristics such as gelatinase production, nitrate reduction and utilization of L-rhamnose and D-xylitol as sole carbon sources (Table 1). In a DNA-DNA relatedness study, performed according to Reddy et al. (2000), strain

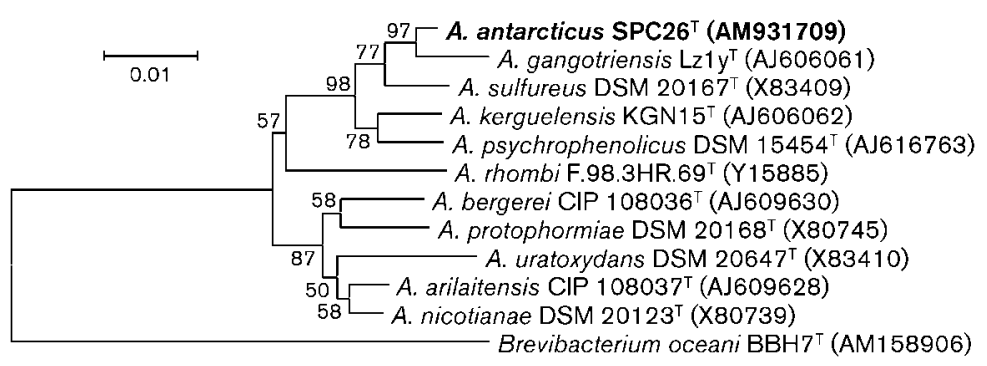

Fig. 1. Neighbour-joining phylogenetic tree based on 16S rRNA gene sequences showing the phylogenetic positions of strain SPC $26^{\top}$ and the type strains of closely related Arthrobacter species. Bootstrap values $(>50 \%)$ based on 1000 replications are shown at branch nodes. The sequence of Brevibacterium oceani $\mathrm{BBH} 7^{\top}$ was used as an outgroup. Bar, 1 substitution per 100 nucleotide positions. 
SPC26 ${ }^{\mathrm{T}}$ showed 35.6, 20.7, 12 and $10 \%$ DNA-DNA relatedness with A. gangotriensis DSM $15796^{\mathrm{T}}$, A. sulfureus DSM $20167^{\mathrm{T}}$, A. psychrophenolicus DSM $15454^{\mathrm{T}}$ and A. kerguelensis DSM $15797^{\mathrm{T}}$, respectively. Reverse DNADNA hybridizations yielded similar results. Considering $70 \%$ DNA-DNA relatedness as the cut-off point for species delineation (Wayne et al., 1987) and the phenotypic and chemotaxonomic differences, strain SPC $26^{\mathrm{T}}$ is regarded as a representative of a novel species of Arthrobacter, for which the name Arthrobacter antarcticus sp. nov. is proposed.

\section{Description of Arthrobacter antarcticus sp. nov.}

Arthrobacter antarcticus (an.tarc'ti.cus. L. masc. adj. antarcticus southern, used to refer to the Antarctic, referring to the isolation of the type strain from Antarctic marine sediment).

Cells are Gram-staining-positive, motile, aerobic and have a rod-coccus cycle. Rod-shaped cells grown in TSB at $22{ }^{\circ} \mathrm{C}$ for $72 \mathrm{~h}$ are $1.5-2.2 \mu \mathrm{m}$ long and $0.2-0.3 \mu \mathrm{m}$ wide. Forms yellow colonies on TSA. Grows at $4-25{ }^{\circ} \mathrm{C}$ (at pH 7, optimum $22-25{ }^{\circ} \mathrm{C}$ ), but not at $30{ }^{\circ} \mathrm{C}$. On TSA, up to $6 \%$ $\mathrm{NaCl}$ is tolerated. Positive for catalase, phosphatase, citrate (Simmons'), lysine and ornithine decarboxylases and nitrate reduction, but negative for indole production, methyl red and Voges-Proskauer tests, $\mathrm{H}_{2} \mathrm{~S}$ production, gelatinase, lipase, $\beta$-galactosidase and DNase. Hydrolyses urea and starch but not aesculin or casein. Produces acid from D-arabinose, D-fructose, D-galactose, D-glucose, rhamnose, sucrose, trehalose, D-xylose and inositol, but not from D-mannose or erythritol. As sole carbon sources, utilizes L-arabinose, D-galactose, D-glucose, melezitose, raffinose, L-rhamnose, salicin, sucrose, trehalose, adonitol, inulin, sodium acetate, D-alanine, L-arginine, L-glutamic acid, glycine, L-lysine, L-proline and L-serine, but not cellobiose, lactose, maltose, D-mannose, melibiose, Lsorbose, dulcitol, erythritol, glycerol, mannitol, D-sorbitol, xylitol, L-asparagine, L-aspartic acid, L-glutamate, L-histidine, L-isoleucine, methionine, L-phenylalanine, L-threonine, tryptophan or L-tyrosine. Resistant to $\left(\mu \mathrm{g} \mathrm{ml}{ }^{-1}\right)$ norfloxacin (25), colistin (25) and nitrofurantoin (30), but sensitive to kanamycin (15), ampicillin (25), tetracycline (10), streptomycin (20) and rifampicin (15). The peptidoglycan diamino acids are lysine and alanine and the acyl type is glutamic acid (A4 $\alpha$ variation). The major menaquinones are MK-8, MK-9 and MK-10. The major polar lipids are phosphatidylethanolamine and diphosphatidylglycerol. The cell-wall sugars are glucose, galactose and rhamnose. Mycolic acid is not present. The major cellular fatty acids $(>5 \%)$ are anteiso- $\mathrm{C}_{15: 0}$, iso- $\mathrm{C}_{15: 0}$, anteiso$\mathrm{C}_{17: 0}$ and anteiso- $\mathrm{C}_{15: 1}$. The DNA $\mathrm{G}+\mathrm{C}$ content of the type strain is $68 \pm 0.5 \mathrm{~mol} \%$.

The type strain is $\mathrm{SPC}^{\mathrm{T}} \mathrm{T}^{\mathrm{T}}\left(=\mathrm{LMG} 24542^{\mathrm{T}}=\mathrm{NCCB}\right.$ $100228^{\mathrm{T}}$ ), isolated from a Southern Ocean sediment from near the Larsemann Hills area of Antarctica.

\section{Acknowledgements}

We would like to thank Dr Bhaskar Bhadra for a critical assessment of the manuscript. We would also like to thank the Director, National Centre for Antarctic and Ocean Research, Goa, India, for providing the samples.

\section{References}

Bhadra, B., Raghukumar, C., Pindi, P. K. \& Shivaji, S. (2008). Brevibacterium oceani sp. nov., isolated from deep-sea sediment of the Chagos Trench, Indian Ocean. Int J Syst Evol Microbiol 58, 57-60.

Chen, M., Xiao, X., Wang, P., Zeng, X. \& Xiao, M. (2005). Arthrobacter ardleyensis sp. nov., isolated from Antarctic lake sediment and deepsea sediment. Arch Microbiol 183, 301-305.

Collins, M. D., Pirouz, T., Goodfellow, M. \& Minnikin, D. E. (1977). Distribution of menaquinones in actinomycetes and corynebacteria. J Gen Microbiol 100, 221-230.

Collins, M. D., Hoyles, L., Foster, G., Falsen, E. \& Weiss, N. (2002). Arthrobacter nasiphocae sp. nov., from the common seal (Phoca vitulina). Int J Syst Evol Microbiol 52, 569-571.

Conn, H. J. \& Dimmick, I. (1947). Soil bacteria similar in morphology to Mycobacterium and Corynebacterium. J Bacteriol 54, 291-303.

Funke, G., Hutson, R. A., Bernard, K. A., Pfyffer, G. E., Wauters, G. \& Collins, M. D. (1996). Isolation of Arthrobacter spp. from clinical specimens and description of Arthrobacter cumminsii sp. nov. and Arthrobacter woluwensis sp. nov. J Clin Microbiol 34, 2356-2363.

Groth, I., Schumann, P., Rainey, F. A., Martin, K., Schuetze, B. \& Augsten, K. (1997). Demetria terragena gen. nov., sp. nov., a new genus of actinobacteria isolated from compost soil. Int J Syst Bacteriol 47, 1129-1133.

Gupta, P., Reddy, G. S. N., Delille, D. \& Shivaji, S. (2004). Arthrobacter gangotriensis sp. nov. and Arthrobacter kerguelensis sp. nov. from Antarctica. Int J Syst Evol Microbiol 54, 2375-2378.

Heyrman, J., Verbeeren, J., Schumann, P., Swings, J. \& De Vos, P. (2005). Six novel Arthrobacter species isolated from deteriorated mural paintings. Int J Syst Evol Microbiol 55, 1457-1464.

Holding, A. J. \& Collee, J. G. (1971). Routine biochemical tests. Methods Microbiol 6A, 2-32.

Hou, X. G., Kawamura, Y., Sultana, F., Shu, S., Hirose, K., Goto, K. \& Ezaki, T. (1998). Description of Arthrobacter creatinolyticus sp. nov., isolated from human urine. Int J Syst Bacteriol 48, 423-429.

Huang, Y., Zhao, N., He, L., Wang, L., Liu, Z., You, M. \& Guan, F. (2005). Arthrobacter scleromae sp. nov. isolated from human clinical specimens. J Clin Microbiol 43, 1451-1455.

Irlinger, F., Bimet, F., Delettre, J., Lefevre, M. \& Grimont, P. A. D. (2005). Arthrobacter bergerei sp. nov. and Arthrobacter arilaitensis sp. nov., novel coryneform species isolated from the surfaces of cheeses. Int J Syst Evol Microbiol 55, 457-462.

Kimura, M. (1980). A simple method for estimating evolutionary rates of base substitutions through comparative studies of nucleotide sequences. J Mol Evol 16, 111-120.

Komagata, K. \& Suzuki, K. (1987). Lipid and cell-wall analysis in bacterial systematics. Methods Microbiol 19, 161-207.

Kumar, S., Tamura, K. \& Nei, M. (2004). MEGA3: integrated software for molecular evolutionary genetics analysis and sequence alignment. Brief Bioinform 5, 150-163.

Lee, J. S., Lee, K. C., Pyun, Y. R. \& Bae, K. S. (2003). Arthrobacter koreensis sp. nov., a novel alkalitolerant bacterium from soil. Int J Syst Evol Microbiol 53, 1277-1280. 
Li, Y., Kawamura, Y., Fujiwara, N., Naka, T., Liu, H., Huang, X., Kobayashi, K. \& Ezaki, T. (2004). Rothia aeria sp. nov., Rhodococcus baikonurensis sp. nov. and Arthrobacter russicus sp. nov., isolated from air in the Russian space laboratory Mir. Int J Syst Evol Microbiol 54, $827-835$.

Margesin, R., Schumann, P., Spröer, C. \& Gounot, A. M. (2004). Arthrobacter psychrophenolicus sp. nov., isolated from an alpine ice cave. Int J Syst Evol Microbiol 54, 2067-2072.

Marmur, J. (1961). A procedure for the isolation of deoxyribonucleic acid from microorganisms. J Mol Biol 3, 208-218.

Minnikin, D. E., Alshamaony, L. \& Goodfellow, M. (1975). Differentiation of Mycobacterium, Nocardia and related taxa by thin-layer chromatographic analysis of whole-organism methanolysates. J Gen Microbiol 88, 200-204.

Minnikin, D. E., Hutchinson, I. G., Caldicott, A. B. \& Goodfellow, M. (1980). Thin layer chromatography of methanolysates of mycolic acid-containing bacteria. J Chromatogr A 188, 221-233.

Osorio, C. R., Barja, J. L., Hutson, R. A. \& Collins, M. D. (1999). Arthrobacter rhombi sp. nov., isolated from Greenland halibut (Reinhardtius hippoglossoides). Int J Syst Bacteriol 49, 1217-1220.

Reddy, G. S. N., Aggarwal, R. K., Matsumoto, G. I. \& Shivaji, S. (2000). Arthrobacter flavus sp. nov., a psychrophilic bacterium isolated from a pond in McMurdo Dry Valley, Antarctica. Int J Syst Evol Microbiol 50, 1553-1561.

Reddy, G. S. N., Prakash, J. S., Matsumoto, G. I., Stackebrandt, E. \& Shivaji, S. (2002). Arthrobacter roseus sp. nov., a psychrophilic bacterium isolated from an Antarctic cyanobacterial mat sample. Int $J$ Syst Evol Microbiol 52, 1017-1021.
Roh, S. W., Sung, Y., Nam, Y. D., Chang, H. W., Kim, K. H., Yoon, J. H., Jeon, C. O., Oh, H. M. \& Bae, J. W. (2008). Arthrobacter soli sp. nov., a novel bacterium isolated from wastewater reservoir sediment. J Microbiol 46, 40-44.

Schleifer, K. H. \& Kandler, O. (1972). Peptidoglycan types of bacterial cell walls and their taxonomic implications. Bacteriol Rev 36, 407-477.

Sly, L. I., Blackall, L. L., Kraat, P. C., Tian-Shen, T. \& Sangkhobol, V. (1986). The use of second derivative plots for the determination of mol\% guanine plus cytosine of DNA by the thermal denaturation method. J Microbiol Methods 5, 139-156.

Smibert, R. M. \& Krieg, N. R. (1994). Phenotypic characterization. In Methods for General and Molecular Bacteriology, pp. 607-654. Edited by P. Gerhardt, R. G. E. Murray, W. A. Wood \& N. R. Krieg. Washington, DC: American Society for Microbiology.

Thompson, J. D., Higgins, D. G. \& Gibson, T. J. (1994). CLUSTAL W: improving the sensitivity of progressive multiple sequence alignment through sequence weighting, position-specific gap penalties and weight matrix choice. Nucleic Acids Res 22, 4673-4680.

Wauters, G., Charlier, J., Janssens, M. \& Delmée, M. (2000). Identification of Arthrobacter oxydans, Arthrobacter luteolus sp. nov., and Arthrobacter albus sp. nov., isolated from human clinical specimens. J Clin Microbiol 38, 2412-2415.

Wayne, L. G., Brenner, D. J., Colwell, R. R., Grimont, P. A. D., Kandler, O., Krichevsky, M. I., Moore, L. H., Moore, W. E. C., Murray, R. G. E. \& other authors (1987). International Committee on Systematic Bacteriology. Report of the ad hoc committee on reconciliation of approaches to bacterial systematics. Int J Syst Bacteriol 37, 463-464. 